УДК 621.362 .2

DOI https://doi.org/10.32838/2663-5941/2021.2-2/09

\title{
Бунько В.Я.
}

Відокремлений підрозділ Національного університету біоресурсів і природокористування України «Бережанський агротехнічний інститут»

\section{Христенко Г.М.}

Відокремлений підрозділ Національного університету біоресурсів і природокористування України «Бережанський агротехнічний інститут»

\section{ДОСЛІДЖЕННЯ ЕФЕКТИВНОСТІ РОБОТИ ГЕЛІОКОЛЕКТОРА}

У иій статті проведено аналіз роботи сонячних елементів, зокрема геліоколектора всесезонного типу, який використовується як джерело альтернативної енергетики для економії техніко-економічних ресурсів.

Проведено аналіз інтенсивності сонячної радіації, яка надходить на перпендикулярну до напрямку випромінювання поверхню, щз залежить від широти і може бути розрахована та знайдена довільними методами. Зокрема, запропоновано метод для визначення середньої інтенсивності сонячної радіації, яка потрапляє та падає на розташовану під будь-яким кутом поверхню до напрямку випромінювання.

Дослідженнями встановлено, щьо найвагоміший вплив на ККД геліоколектора мають такі фактори, як: інтенсивність сонячної енергії та температура навколишнього середовища, конструктивні параметри і характеристики сонячного колектора, а також властивості теплопоглинаючої поверхні, зокрема, матеріал і товщина поверхні колектора, товщина ізолячї та коефіцієнт теплопровідності иієї ізоляиії, відстань-крок труб, пропускна здатність скла, робочі параметри геліоколектора витрата теплоносія і його температура на вході.

3 метою підвищення ефективності роботи геліоколектора обтрунтовано важливість та правильність проведення відповідних розрахунків для знаходження оптимальних кутів його встановлення, за яких буде отримано максимально можливу кількість поглинутої сонячної енергії для ефективного використання сонячного колектора та параметрів робочого агента теплової енергії.

Проведено порівняльний аналіз вакуумних та плоских геліоколекторів. Наведено результати потужності колекторів в залежності від часу доби у різних місяиях року. Потужність колектора залежить від інтенсивності сонячної радіації протягом доби та інсоляџійного періоду. Встановлено, щчо вакуумний колектор дає кращі показники під час виробництва теплової енергії практично в усіх місяиях року.

Наведено графік накопичення сонячної радіаџії у відсотках, яка безпосередньо залежить від правильності улаштування сонячного колектора - кута нахилу та орієнтаиії встановлення даної геліоустановки.

Ключові слова: геліоколектор, сонячна енергія, теплова енергія, інсоляція, альтернативні джерела, сонячна радіачія.

Постановка проблеми. Широке впровадження та інтенсивне використання традиційних джерел енергії у всьому світі призвело до появи ряду екологічних проблем, найбільш гострими 3 яких є збільшення викидів в атмосферу вуглекислого газу та зменшення товщини озонового шару.

На сьогоднішній день розроблено та використовується значна кількість сонячних установок (геліоколекторів, фотоелектричних елементів тощо) різних конструкцій, що відрізняє їх за техніко-економічними показниками. Більшість геліоколекторів виготовляється у формі плоских конструкцій, істотним недоліком яких $є$ нестабільність ефективності іх роботи впродовж світлового дня (знижується до $60 \%$ в ранішні та вечірні години), висока вартість і трудомісткість виготовлення.

Враховуючи стрімкий розвиток енергозберігаючих технологій з використанням альтернативних джерел енергії, великі перспективи має розробка та проєктування таких інженерно-технологічних рішень, які забезпечуватимуть можливість поєднання конструктивних та архітектурних функцій окремих елементів будівель та споруд 3 одночасним поглинанням ними сонячної енергії і перетворення іiі на теплову енергію при зниженні матеріальних і трудових затрат.

Аналіз останніх досліджень і публікацій. Дослідженнями інсоляційного режиму займались такі вчені, як О.В. Сергейчук, М.В. Омельяненко, 
А.Я. Штейнберг, М.Б. Яців та інші. Деякі питання альтернативної енергетики різних країн світу в своїх працях досліджували такі науковці: Р.М. Буквич, Г.Г. Гелетуха, П.П. Кучерук, Е.Н. Олейник, А.В. Трибой, І.В. Замула, А.В. Кирейцева.

Питання щодо використання альтернативних джерел енергії, зокрема сонячних колекторів, обговорюються фахівцями в цій галузі та вченими як всього світу, так і України зокрема на міжнародних, всеукраїнських конференціях, симпозіумах щодо впровадження відновлювальних джерел енергії у всіх сферах людської діяльності, зокрема на II Міжнародній науковопрактичній конференції «Використання альтернативних джерел енергії в умовах розвитку сільських територій» м. Полтава, 2019; Міжнародній науково-практичній конференції «Перспективи використання альтернативних і поновлюваних джерел енергії в Україні (REU 2014)»; XXI міжнародній науково-практичній інтернетконференції «Відновлювана енергетика та енергоефективність у XXI столітті» м. Київ, 2020 (Інститут відновлюваної енергетики НАН України) та інші.

Виклад основного матеріалу. Відомо, що сонячна радіація надходить до Землі у вигляді електромагнітних хвиль, котрі кількісно характеризуються питомою густиною потоку випромінювання та вимірюються у Вт/м² [4]. Цю величину також ще називають питомою потужністю, енергетичною освітленістю або інтенсивністю випромінювання. Такі дані про зміну сонячної енергії протягом певного дня чи року можна отримати 3 відповідних літературних джерел [5].

Слід відмітити, що системи сонячних колекторів для нагріву максимальної кількості гарячої води і максимальної економії енергоресурсів потребують встановлення якомога більшої площі сонячних колекторів.

Але в найбільш спекотні літні дні це може призводити до того, що колектори будуть виробляти «надлишкове» тепло, що приведе до закипання теплоносія в колекторах і зупинки в роботі всієї системи.

Для таких систем відомі компанії пропонують сонячні колектори, які самостійно регулюють максимальну робочу температуру і здатні надійно захищати систему від закипання: наприклад вакуумні колектори Vitosol 300-T типу SP3B і нові плоскі колектори Vitosol 100-FM та Vitosol 200-FM 3 абсорбером ThermProtect, що змінює свої властивості в залежності від робочої температури [13].

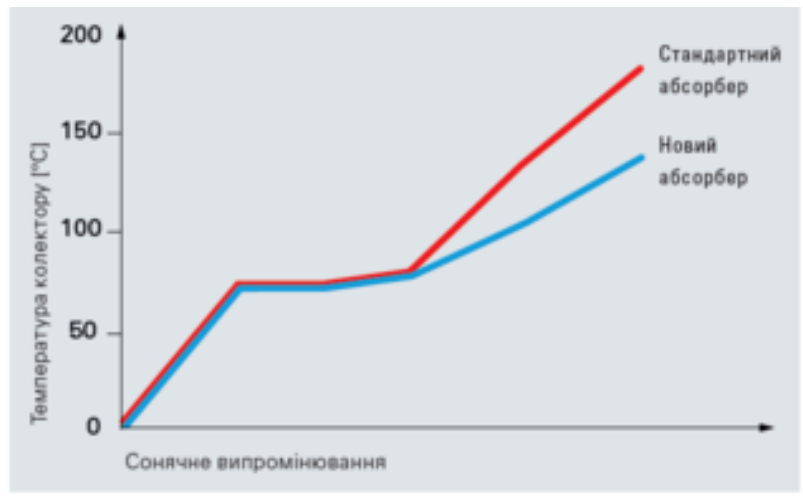

Рис. 1. Залежність температури геліоколектора від сонячного випромінювання (графік захисту від закипання теплоносія)

Всесезонний сонячний колектор постійно виробляє теплову енергію, коли на нього потрапляє сонячне випромінювання. Навіть тоді, коли в цьому теплі немає потреби. Наприклад, влітку, коли теплоносій не використовується для жодних потреб. Сонячні колектори нагрівають наявні баки запасу гарячої води в буферну ємність (теплоакумулятор). Коли ж гарячу воду ніхто не використовує, то геліостанції нагрівають теплоносій в акумуляторі тепла до максимальних температур і вимикаються за допомогою системи автоматичного контролю та управління.

Слід врахувати, що коли при цьому на геліоколектор буде потрапляти значна частина сонячних променів, яка підвищить інтенсивність сонячного випромінювання, то це призведе до закипання в ньому теплоносія. А тому цей процес негативно впливає на сам теплоносій, оскільки термін його експлуатації буде зменшуватись. Водночас відповідних термічних навантажень зазнають і самі компоненти такої системи: трубопроводи, арматура, ущільнення, циркуляційний насос тощо. В окремих сонячних колекторах з інноваційним абсорбером ThermProtect [13] закипання теплоносія гарантовано виключається.

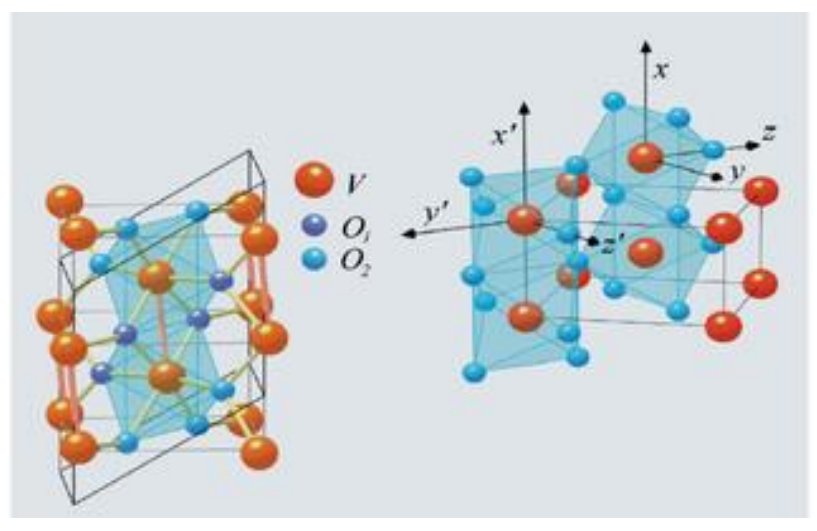

Рис. 2. Зміна оптичних властивостей абсорберу [13] 
Новий абсорбер складається з багатьох шарів. Один 3 цих шарів складає оксид ванадію $\left(\mathrm{VO}_{2}\right)$. При температурах вище $+75^{\circ} \mathrm{C}$ оксид ванадію починає змінювати свої оптичні властивості. При розігріванні значно збільшується його теплове випромінювання i завдяки цьому зменшується температура колектору. I чим вище буде температура абсорберу, тим вище буде його теплове випромінювання. Особливо сильно цей ефект проявляється при температурах абсорберу від $+100^{\circ} \mathrm{C}$. При температурі $+150^{\circ} \mathrm{C}$ він повністю випромінює тепло, що попадає на нього з сонячними променями Кількість змін структури кристалів шарів селективного покриття не обмежена, що гарантує довготривалий термін експлуатації сонячних колекторів [3].

Як тіло 3 середньою температурою близько 5762 К сонце випромінює електромагнітні хвилі різної довжини, які разом складають відповідний сонячний спектр $[1 ; 5 ; 12]$. За довжиною хвилі $\lambda$ такий спектр умовно поділяють на три діапазони, а саме: ультрафіолетовий, видимий та інфрачервоний. Перші два діапазони ще називаються короткохвильовими, а інфрачервоний довгохвильовим $[1 ; 4 ; 12]$. На приймач-споживач біля поверхні землі сонячна радіація надходить у вигляді трьох потоків: прямого, розсіяного та відбитого від рельєфу та навколишніх поверхонь. Певними дослідженнями та обгрунтуваннями встановлено, що практично вся енергія цих потоків сонячної радіації надходить в область коротких довжин хвиль, причому основна частина потрапляє на видиму та ближню інфрачервону область спектру $[1 ; 5 ; 12]$.

Найбільша густина потоку сонячного випромінювання, яке надходить на земну поверхню, становить $1 \mathrm{\kappa BT} / \mathrm{M}^{2}$ з діапазоном довжини хвиль 0,2-3 мкм $[1 ; 5 ; 12]$. Таке випромінювання називається короткохвильовим та включає видимий спектр. Під час проходження сонячного проміння через атмосферу Землі частина випромінювання розсіюється і поглинається озоном, повітрям та водяною парою, а також частинками пилу, що приводить до послаблення прямого сонячного випромінювання $[1 ; 4 ; 5 ; 12]$. Часто необхідні дані про сонячну енергію відсутні, тому для цього використовують графічні та аналітичні залежності, котрі дають можливість вирішувати поставлені завдання. Знаходження та опис таких залежностей описано в багатьох наукових працях $[7 ; 8 ; 9 ; 10 ; 12]$.

Інтенсивність випромінювання сонячної радіації $I_{s}$, яка надходить на поверхню, перпендику- лярну до напрямку випромінювання, залежить від широти і може бути знайдена за відповідними формулами та методами. Для розрахунку такого показника $I_{6}$ для широти $38^{\circ}-64^{\circ}$ доцільною $є$ формула $[1 ; 11 ; 12]$ :

$$
I_{\text {B }}=\frac{Q_{0} \cdot \sin h}{\sin h+c},
$$

де $h$ - висота сонячного стояння для певної окремої місцевості в певну годину доби, град; $c$ - емпіричний показник, що характеризує прозорість (видимість) атмосфери; $Q_{0}$ - інтенсивність сумарної сонячної радіації за безхмарного чистого неба, Вт/ ${ }^{2}$.

Для широти $0^{\circ}-37^{\circ}$ та $65^{\circ}-90^{\circ}$ ця величина визначається за формулою $[1 ; 11 ; 12]$ :

$$
I_{\theta}=Q_{0} \cdot\left(\frac{r_{0}}{r}\right)^{2} \cdot \frac{\sin h}{\sin h+c},
$$

де $r_{0}$ - середня відстань від Землі до Сонця, м; $r$ - відстань від Землі до Сонця в певний період року, м.

Середню інтенсивність сонячної радіації $I_{c p}$, яка падає на розташовану поверхню під будьяким кутом до напрямку випромінювання, можна розрахувати за формулою $[1 ; 5 ; 12]$ :

$$
I_{c p}=I_{\sigma} \cdot \cos \theta,
$$

де $\cos \theta$ - косинус кута між напрямком випромінювання і нормаллю до поверхні.

Проте слід провести порівняльний аналіз сонячних колекторів на основі вакуумних трубок або плоских колекторів.

В останні десять років, 3 тих пір, як альтернативна енергетика стала більш доступною для широкого кола споживачів, і сонячні колектори почали активно впроваджуватись в системах опалення та гарячого водопостачання, тема порівняння продуктивності, а так само інших характеристик плоских та вакуумних колекторів, неодноразово обговорювалась на конференціях, семінарах та виставках і викликала між апологетами цікаву дискусію, яку слід зобразити графічно для того, щоб зрозуміти та дати відповідь на це питання [2].

Для початку представимо графіки реального виробництва двох колекторів апертури (ефективної поглинаючої площі сонячного колектора), які здебільшого займають більшу частину ринку подібних геліосистем. Такий тип сонячних колекторів працює не в лабораторних умовах, а в реальних, тому цей графік максимально точно дозволить описати роботу сонячних колекторів вакуумного та плоского типу. Теорія цього процесу доволі проста, оскільки вакуумний колектор 
має вакуум між абсорбером і склом, яке безпосередньо контактує з атмосферою. Плоский колектор такого вакууму не має. Відповідно, вплив зовнішнього середовища на вакуумний колектор істотно менший, ніж плоский. Особливе значення в цьому процесі мають температурне та вітрове навантаження [2].

T1 - температура поверхні колектора 3 вакуумними трубками; Т2 - температура теплоносія в акумуляторі тепла; R1 - циркуляційний насос.

Проаналізувавши усі графіки (рис. 4-7), можна сказати, що вакуумний колектор дає кращі показники під час виробництва теплової енергії практично в усіх місяцях року. Як показує практика, варто зазначити, що у разі правильного встановлення вакуумного колектора його загальне річне виробництво тепла перевищує виробництво теплової потужності плоского не менш ніж на
$20 \%$ [2]. Проте слід розуміти, що правильне улаштування геліоколектора передбачає дотримання окремих аспектів, котрі мають місце в зимовий період: вакуумний колектор не повинен засипатись снігом зважаючи на малий кут нахилу; колектор не повинен знаходитись в положенні, коли він лежить прямо на даху приміщення і шар снігу просто покриває його повністю, а почистити немає можливості.

На рис. 8 зображено графік накопичення сонячної радіації у відсотках, яка безпосередньо залежить від правильності улаштування сонячного колектора - кута нахилу та орієнтації встановлення даної геліоустановки.

Висновки. Отже, враховуючи всі аспекти проєктування, розрахунку та впровадження сонячних колекторів для системи теплопостачання, слід враховувати особливості вибору таких систем,

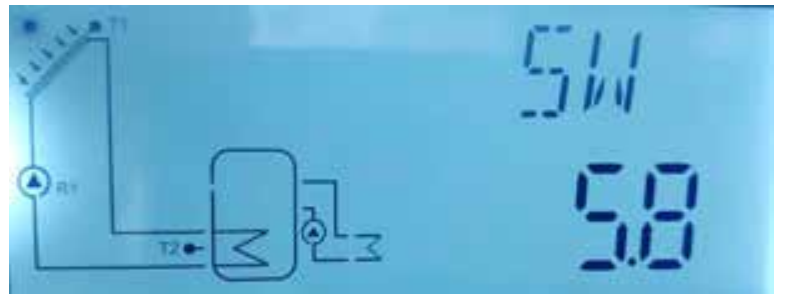

Рис. 3. Індикаторні параметри діючого геліоколектора 3 вакуумними трубками

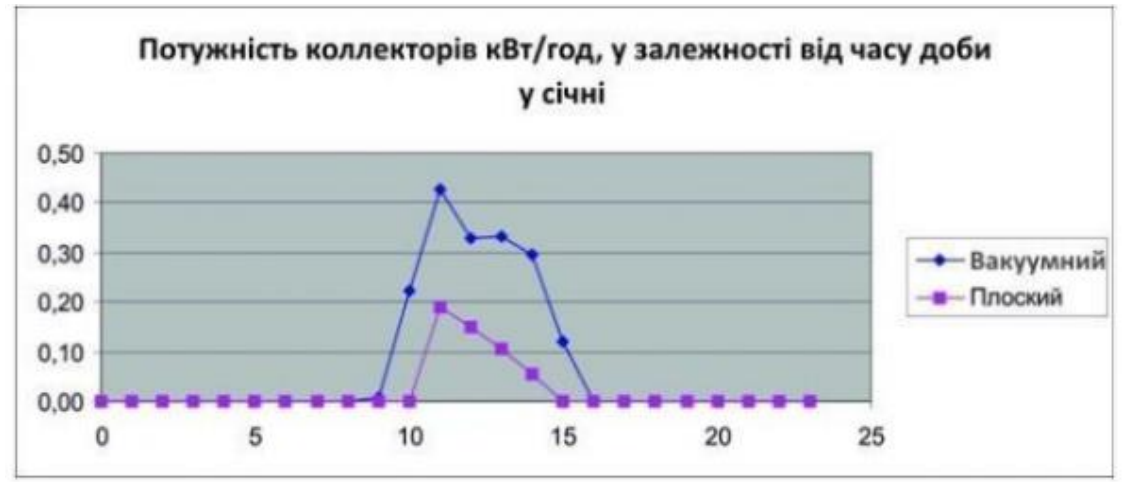

Рис. 4. Потужність колекторів в залежності від часу доби у січні місяці [2]

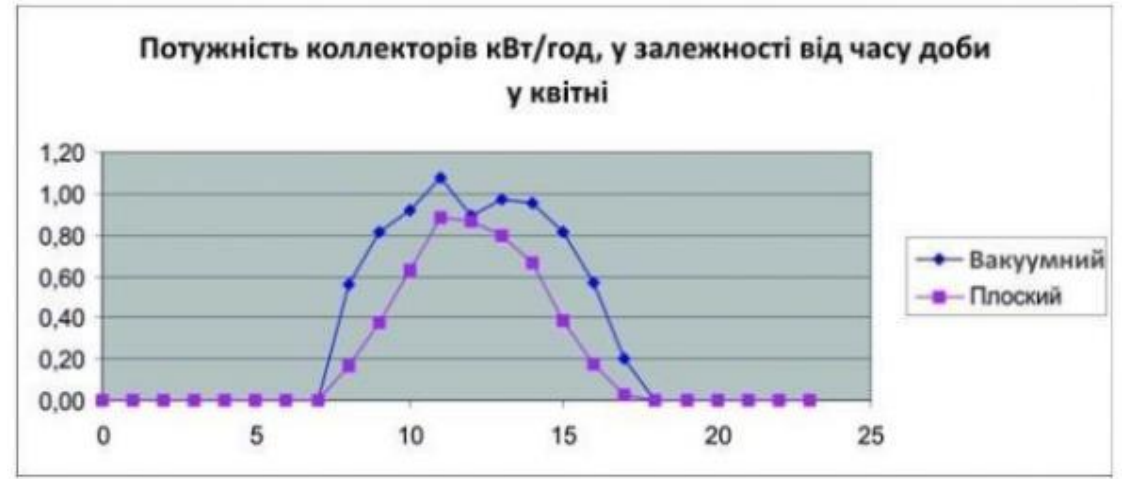

Рис. 5. Потужність колекторів в залежності від часу доби у квітні місяці [2] 


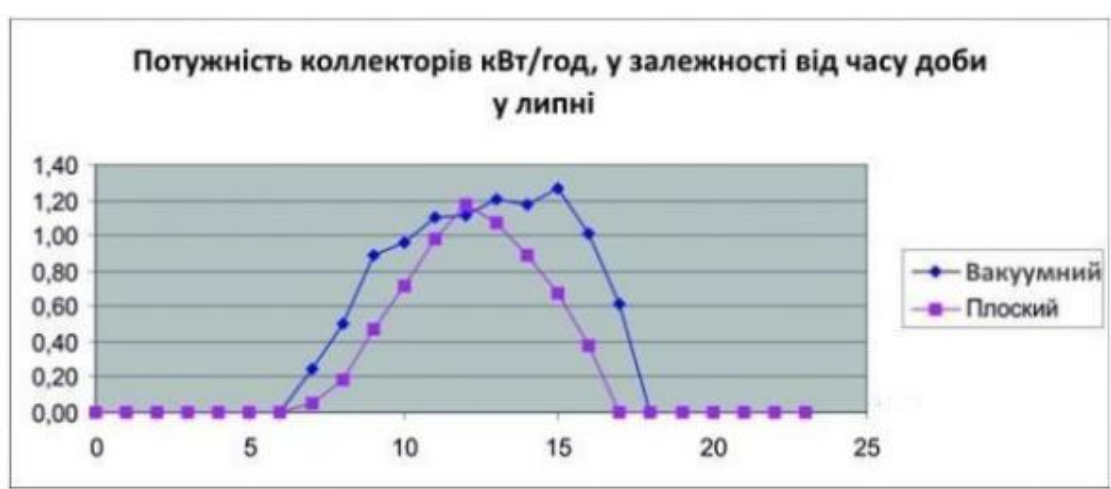

Рис. 6. Потужність колекторів в залежності від часу доби у липні місяці [2]

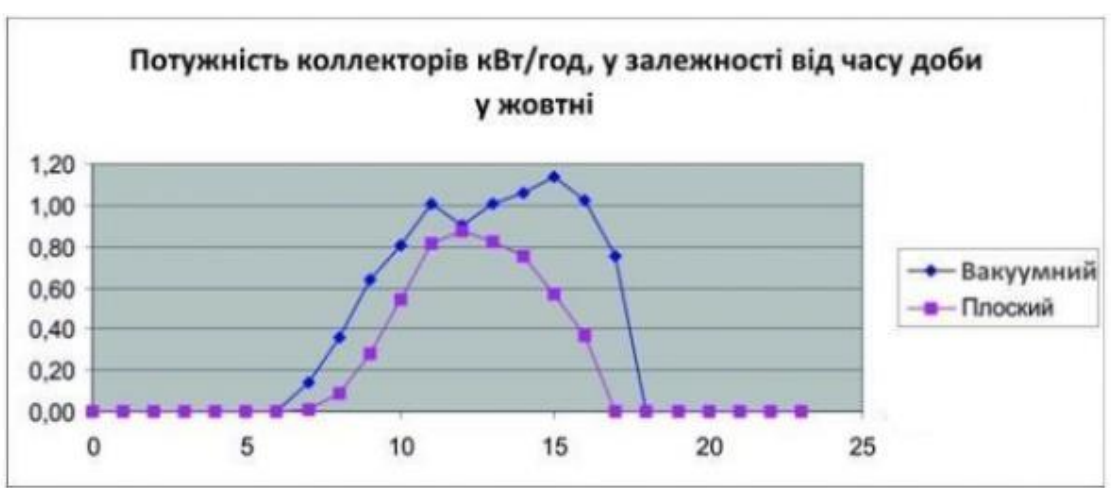

Рис. 7. Потужність колекторів в залежності від часу доби у жовтні місяці [2]

\section{Нахил і орієнтація колектора}

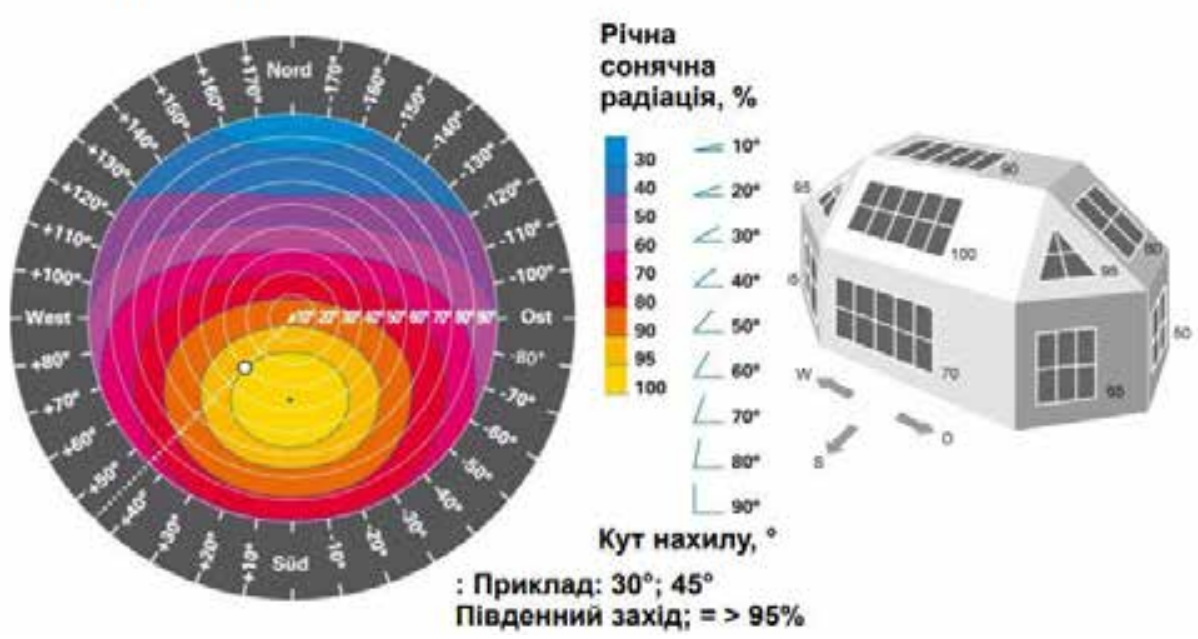

Рис. 8. Визначення річної сонячної радіації в залежності від кута нахилу та орієнтації колектора [3]

правильно улаштовувати, передбачити окремі розрахунки кута нахилу колектора для ефективної інтенсифікації процесу інсоляції, що дасть можливість підвищити ККД геліосистеми в цілому. Провівши порівняльний аналіз вакуумних та плоских колекторів, варто зазначити, що плоский колектор втрачає частину тепла шляхом прямого теплопереносу від абсорбера до скла і далі - назад в атмосферу. Причому ці втрати тим більші, чим більша різниця температур між внутрішньою частиною плоского колектора і температурою повітря 3 зовні. А тому такі дослідження будуть мати подальше обгрунтування та перспективи в сфері альтернативної енергетики. 


\section{Список літератури:}

1. Кондратьев К.Я. Актинометрия. Ленинград : Гидрометеорологическое издательство, 1965. 690 с.

2. URL: https://teplocel.com.ua/ne-vyvodyty/sonyachnyj-kolektor-yakyj-vybraty-ploskyj-abo-vakuumnyj/ (дата звертання 20.03.2021).

3. URL: https://snabrezerv.ua/upload/medialibrary/374/rez.kollektory12-05-2017.pdf (дата звертання 22.03.2021).

4. Гальчак В., Боярчук В. Альтернативні джерела енергії : навч. посіб. Львів : Арал, 2008. 135 с.

5. Даффи Дж. А., Бекман У. А. Тепловые процессы с использованием солнечной энергии / пер. с англ. под. ред Ю.Н. Малевского. Москва : Мир, 1977. 420 с.

6. Perers B. Dynamic method of solar collector testing. Solar Energy Engng 2. P. 1149-1154, 1992.

7. Голицын М.В., Голицын А.М., Пронина Н.М. Альтернативные энергоносители. Москва : Наука, 2004. $159 \mathrm{c}$.

8. Ляшенко М.Б., Реджепова Ш. Р. Математическое моделирование и оптимальное проектирование некоторых хозяйственных гелиотехнических систем. Ашхабад : Ылым, 1989. 124 с.

9. Магомедов М.А. Нетрадиционные возобновляемые источники энергии. Махачкала : Юпитер, 1996. $245 \mathrm{c}$.

10. Максимова Н.А. Енергозберігаючі системи на основі абсорбційних термотрансформаторів: автореф. дис. на здобуття наук. ступеня канд. техн. наук: 05.23.03. Макіївка, 2007. 19 с.

11. Твайделл Д., Уэйр А. Возобновляемые источники энергии / пер. с англ. под ред. В.А. Коробкова. Москва : Энергоатомиздат, 1990. 391 с.

12. Пона О.М. Підвищення ефективності комбінованої системи теплопостачання 3 геліопокрівлею: дис.... канд. техн. наук. Львів, 2018. 201 с.

13. URL: http://xn--80avikb.xn--j1amh/page/geliosistemi (дата звертання 21.03.2021).

\section{Bunko V.Ya., Khrystenko H.M. STUDY OF THE EFFICIENCY OF THE HELIOCOLLECTOR}

This article analyzes the operation of solar cells, in particular the all-season solar collector, which is used as a source of alternative energy to save technical and economic resources.

The analysis of the intensity of solar radiation, which enters the surface perpendicular to the direction of radiation, depends on the latitude and can be calculated and found by arbitrary methods. In particular, a method is proposed to determine the average intensity of solar radiation that falls and falls on the surface located at any angle to the direction of radiation.

Studies have shown that the most significant influence on the efficiency of the solar collector are factors such as: solar energy intensity and ambient temperature, design parameters and characteristics of the solar collector, as well as heat-absorbing surface properties, including material and collector surface thickness, insulation thickness and thermal conductivity, distance-step of pipes, capacity of glass, working parameters of a solar collector - a expense of the heat carrier and its temperature on an entrance.

In order to increase the efficiency of the solar collector, the importance and correctness of appropriate calculations to find the optimal angles of its installation, at which the maximum possible amount of absorbed solar energy for efficient use of the solar collector and the parameters of the working agent of thermal energy.

A comparative analysis of vacuum and flat solar collectors was performed. The results of reservoir capacity depending on the time of day in different months of the year are given. The power of the collector depends on the intensity of solar radiation during the day and the insolation period. It is established that the vacuum collector gives the best indicators in the production of thermal energy in almost all months of the year.

The graph of accumulation of solar radiation in percent which directly depends on correctness of the arrangement of a solar collector - an angle of inclination and orientation of installation of the given solar installation is resulted.

Key words: solar collector, solar energy, thermal energy, insulation, alternative sources, solar radiation. 